\title{
An update on the cerebellar subtype of multiple system atrophy
}

\author{
Ludovico Ciolli ${ }^{1,2}$, Florian Krismer ${ }^{2}$, Ferdinando Nicoletti ${ }^{3,4}$ and Gregor K Wenning ${ }^{2 *}$
}

\begin{abstract}
Multiple system atrophy is a rare and fatal neurodegenerative disorder characterized by progressive autonomic failure, ataxia and parkinsonism in any combination. The clinical manifestations reflect central autonomic and striatonigral degeneration as well as olivopontocerebellar atrophy. Glial cytoplasmic inclusions, composed of a-synuclein and other proteins are considered the cellular hallmark lesion. The cerebellar variant of MSA (MSA-C) denotes a distinctive motor subtype characterized by progressive adult onset sporadic gait ataxia, scanning dysarthria, limb ataxia and cerebellar oculomotor dysfunction. In addition, there is autonomic failure and variable degrees of parkinsonism. A range of other disorders may present with MSA-C like features and therefore the differential diagnosis of MSA-C is not always straightforward. Here we review key aspects of MSA-C including pathology, pathogenesis, diagnosis, clinical features and treatment, paying special attention to differential diagnosis in late onset sporadic cerebellar ataxias.
\end{abstract}

Keywords: Multiple system atrophy, Cerebellar type, Idiopathic late onset cerebellar ataxia, Sporadic adult onset ataxia

\section{Introduction}

Multiple system atrophy (MSA) is a rare, sporadic, progressive, neurodegenerative disorder combining features of parkinsonism, autonomic dysfunction and cerebellar and pyramidal signs. MSA can be further classified in parkinsonian-type MSA (MSA-P) and cerebellar-type MSA (MSA-C) according to the predominant motor symptoms at evaluation.

MSA has a prevalence of $1.9-4.9$ cases per $100000[1,2]$ and an incidence of $0.6 / 100000$, raising up to $3 / 100000$ in people older than 50 years [3].

MSA-P is the more common variant in Europe and in USA, accounting for about $65 \%$ of all cases [4-6]. In the Japanese population MSA-C is present in $83.8 \%$ of MSA patients at first examination and in $48.6 \%$ of patients at last follow-up [7]. This difference could be caused by, not yet fully understood, genetic predisposition and environmental influences in the pathogenesis of the disease. Median survival ranges from 6 years to about 9 years $[6,8,9]$.

Here, we aim to provide an update on the pathology, pathogenesis, diagnosis, clinical presentation and latest

\footnotetext{
* Correspondence: gregor.wenning@i-med.ac.at

${ }^{2}$ Department of Neurology, Innsbruck Medical University, Anichstrasse 35, A-6020 Innsbruck, Austria

Full list of author information is available at the end of the article
}

therapeutic development in MSA-C. We searched the following terms on PubMed: "multiple system atrophy", "idiopathic late onset cerebellar ataxia", "sporadic adult onset ataxia". In addition, reference lists in review papers were systematically checked for relevant references. Only papers in English were reviewed.

\section{Review \\ Pathology}

Twenty years ago Papp and coworkers identified, for the first time, the argyrophilic filamentous aggregates localized in the cytoplasm of oligodendrocytes that were common to all MSA variants. These inclusion bodies were subsequently termed glial cytoplasmic inclusions (GCIs) or Papp-Lantos bodies [10]. GCIs are typically associated with gliosis and neuronal loss in the basal ganglia, cerebellum, pons, inferior olivary nucleus, and spinal cord. Frequently a striatonigral (SND) or olivopontocerebellar (OPCA) pattern of atrophy can be defined. Patients can present either a balanced damage in both regions or a predominant involvement of one system over the other. In both cases, the pathological alteration determines the clinical phenotype, i.e. clinically diagnosed MSA-C often reflects underlying OPCA [11-14]. In MSA pathological alterations are not limited to OPCA and SND but many 
other brain regions can be involved. Degeneration of several autonomic nuclei in the brainstem and spinal cord is traditionally believed to account for autonomic failure in MSA [15-17]. However, a growing body of evidence suggests that post-ganglionic denervation also occurs in MSA patients, and may be involved in the pathogenesis of dysautonomia [18-21]. Accordingly, the sudomotor nerve density in the sweat glands has been found to be reduced in patients with MSA as compared to healthy controls. Interestingly, peripheral nerve degeneration has been found in the early course of the disease, and may, therefore, be independent of degeneration of autonomic CNS nuclei [21].

In the late 1990's, $\alpha$-synuclein was identified as the main component of GCIs [22-25]. Widespread GCIs cannot be found in other diseases and are always present in patients with MSA, regardless of the clinical phenotype. Their assessment is considered as the only reliable criteria for the diagnosis of definitive MSA $[26,27]$. Additionally, neuronal cytoplasmic inclusions (NCIs) and neuronal nuclear inclusions (NNIs) can be found in MSA as well, however, they are only of limited diagnostic value [28].

Of note, however, $\alpha$-synuclein is not the only component of GCIs. Ubiquitin, tau, p25 $\alpha$, members of the heat shock protein family, dopamine and c-AMP-regulated phosphoprotein-32 (DARPP-32), and many other proteins have been detected in different proportion in GCIs [17]. Of interest, p25 $\alpha$, a normal constituent of myelin sheets in healthy neurons, seems to have a facilitatory effect on GCIs formation, and its dislocation from the axons to the soma of oligodendrocytes [29] might therefore have a causative role in $\alpha$-synuclein aggregation [30].

\section{Pathogenesis}

Aberrant protein aggregation and dislocation can enhance neuronal demise [31,32] by disrupting the cytoskeleton [33]. While NNIs and NCIs directly damage neurons, GCIs primarily promote oligodendrocytes death [34-36], thereby causing secondary neurodegeneration. This assumption is also supported by evidence that GCI density correlates with disease duration and neuronal loss [13].

The most accredited theory linking oligodendrocyte damage with neuronal death focuses on disruption of the crosstalk between these cells. Oligodendroglial dysfunction results into an abnormal synthesis and release of trophic factors and other signal molecules, thereby triggering neuronal apoptosis [13,37].

Dysfunction of the mitochondrial respiratory chain may also contribute to the pathophysiology of MSA, as suggested by the evidence that variants in the COQ2 gene that reduce the function of parahydroxybenxzoate-polyprenyltransferase (an enzyme necessary for the biosynthesis of coenzyme $\mathrm{Q}_{10}$ ) are associated with an increased risk of developing MSA [38]. Mitochondrial dysfunction leads to an excessive production of reactive oxygen species (ROS) [39,40], which have been implicated in the pathogenesis of MSA-associated neuronal damage [41,42]. ROS species are also generated by activated microglia, together with other damaging factors, such as nitrogen species and cytokines [43-45] (Figure 1) [17]. Microglial activation can be partially explained by an aberrant expression of Toll-like receptors (TLRs) in brain regions involved in OPCA and SND [46]. An imbalance of TLR signaling could enhance MSA-related brain injury by promoting pro-inflammatory signals $[47,48]$.

In spite of the recent advances in the understanding of the pathogenesis of MSA, many questions remain unanswered. The influence of environmental and genetic factors remain unresolved in the western hemisphere. Although early reports suggested an association between MSA and agricultural work, the role of toxic substances could not be unequivocally proven [33]. Genetic inheritance is uncommon and there are few reports of familiar MSA in the literature [49-51]; however, the genetic background is important and single nucleotide polymorphisms (SNPs) of the genes encoding $\alpha$-synuclein [52-54], the prion protein [55], and loss of function mutations of the phenylbenzoate-polyprenyltransferase were shown to be associated with an increased risk of MSA [38].

The origin of the $\alpha$-synuclein found in GCIs is still unknown. Miller and coworkers failed to detect the expression of the gene coding for $\alpha$-synuclein (the SNCA gene) in oligodendrocytes using double-labeling in situ hybridization technique [56]. Recently, however, $\alpha$-synuclein mRNA could be measured in oligodendrocytes by laser-capture microdissection technique. mRNA levels in oligodendrocytes did not differ between MSA patients and healthy controls, although there was a trend to an increase in MSA patients [57]. Proteosomal and autophagic degradation of $\alpha$-synuclein has also been found to be impaired in affected oligodendrocytes $[17,56,58]$.

An increased uptake of $\alpha$-synuclein from the extracellular environment, particularly from the cerebrospinal fluid (CSF) [59], may also contribute to GCI formation and propagation [60,61]. Reyes et al. (2014) [61] have shown that oligodendrocytes grafted in the striatum of rats overexpressing human $\alpha$-synuclein, take-up the protein from surrounding axon terminals. This evidence suggests a prion-like propagation of $\alpha$-synuclein in MSA, similarly to what hypothesized for Parkinson's disease $[62,63]$.

\section{Clinical features}

MSA-C patients develop the first motor or autonomic symptoms at the mean age of 56 years $[64,65]$. Postmortem confirmed MSA-C has never been reported in patients younger than 30 years. If symptoms appear for the first 


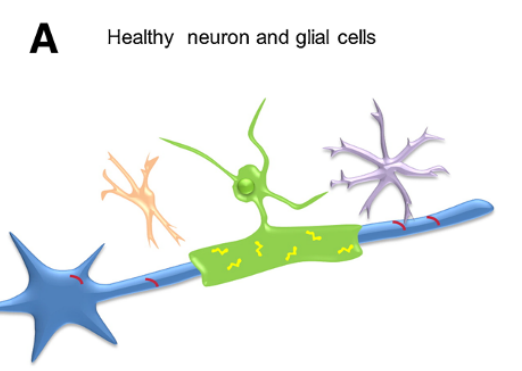

B Relocation of $\mathrm{p} 25 \mathrm{\alpha}$ from processes to the soma, soma increased in size

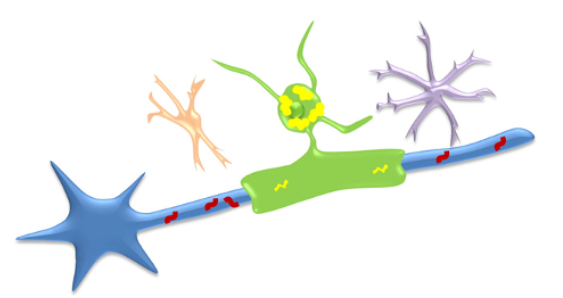

C a-Syn accumulation in the oligodendroglial

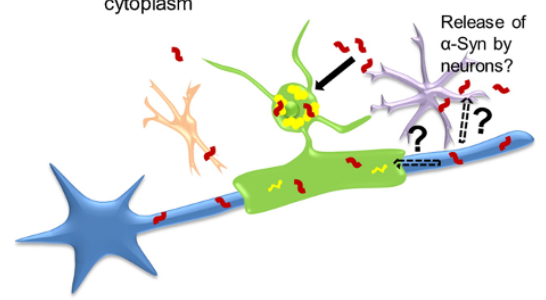

D Formation of characteristic GCls containing $\alpha$ -
Syn and $p 25 \alpha$

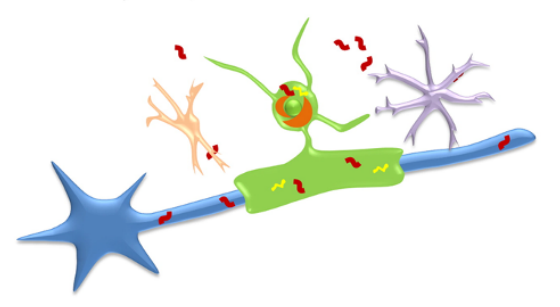

E Disrupted trophic support, impaired mitochondria, proteasomal dysfunction, increased ROS production

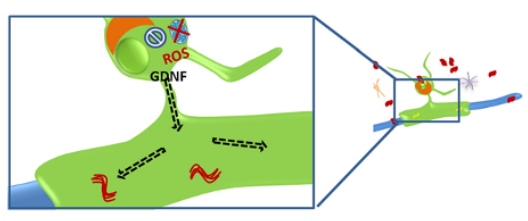

F Degenerating oligodendrocyte

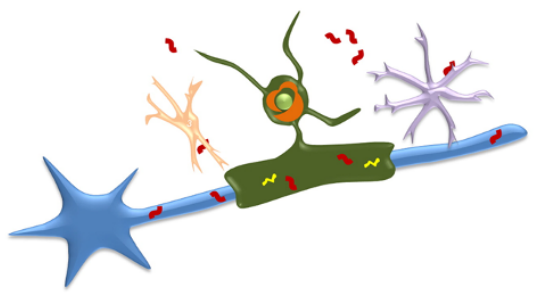

G Secondary neuronal loss?
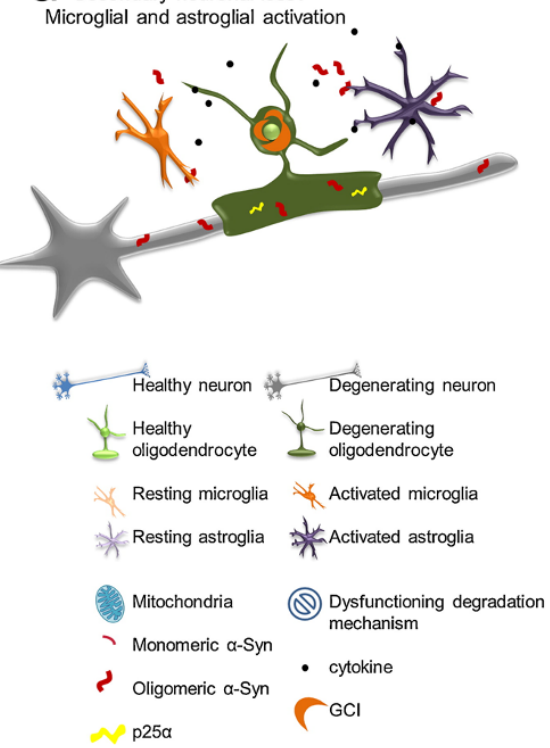

Figure 1 Possible pathological a-Syn-spreading and accumulation mechanism leading to neurodegeneration. (A) Healthy neuron, oligodendrocyte, microglia and astrocyte, p25a mainly located in the myelinating oligodendroglial processes, monomeric a-Syn present in presynaptic nerve terminals. (B) Relocalisation of p25a from the processes to the soma, inclusion formation and swelling of the oligodendroglial soma. (C) Oligomeric a-Syn accumulation in the oligodendroglial cytoplasm, the exact source of a-Syn remains to be investigated. Possible hypotheses include exocytosed a-Syn from neurons and uptake into oligodendrocytes by cell-to-cell propagation or upregulation of a- Syn expression in oligodendrocytes themselves. In addition, axonal a-Syn may be taken up by the dysfunctional oligodendroglial myelin compartment. (D) a-Syn aggregates form insoluble half-moon shaped GCls characteristic for the disease. (E) Disruption of trophic support (e.g. GDNF), mitochondrial failure, increased production of reactive oxygen species (ROS) and proteasomal dysfunction occur. (F) Oligodendrocytes suffer from severe distress and will eventually degrade. (G) Activation of micro/astroglial cells by cytokines released from the damaged oligodendrocytes, proposed secondary neuronal loss potentially due to lack of trophic support, ROS production, proteasomal failure and pro-inflammatory environment. Reproduced with the courtesy of Elsevier.

time in patients older than 75 years, the diagnosis of MSA should be questioned [27]. Motor symptoms in MSA-C are often preceded by autonomic and other non-motor features $[15,64]$. Erectile dysfunction and urinary problems, such as incontinence and urinary retention, are frequently the first manifestation of autonomic failure in MSA-C $[15,64,66,67]$. Postural faintness tends to occur later $[15,64,66,68]$. Other symptoms of autonomic failure in MSA-C include reduced sweating and constipation. Recently, Iodice and colleagues (2012) [69] reported that 
the most common cerebellar feature at motor presentation is ataxic gait, followed by dysarthria, limb ataxia and gazed-evoked nystagmus. Although nystagmus is uncommon, other oculomotor abnormalities, such as jerky pursuit, square wave jerks, and dysmetric saccades are frequently observed in the early course of the disease [27]. Hyperreflexia and positive Babinski sign are classical manifestations of pyramidal tract degeneration and are frequently assessed in MSA-C patients.

Parkinsonism occurs about 5 years after the onset of MSA-C [70] and is usually characterized by an akineticrigid syndrome. Parkinsonian symptoms in MSA-C patients may respond to levodopa (L-DOPA) in up to $51 \%$ of cases, however, the effect is often transient and some patients also develop L-DOPA-induced dyskinesias [65].

Craniocervical dystonia is a common cause of postural aberrations such as camptocormia and Pisa syndrome. Dystonic involvement of face, hands and feet is also possible. Laryngeal abductor palsy resulting in stridor, can also be present. It commonly appears late in the disease course and is a possible cause of sudden death [71].

Ataxia, parkinsonism and postural impairment all contribute to gait instability, occurring early after the disease onset $[64,72]$.

Microcirculatory abnormalities are common in MSA-C patients and are responsible for the so called "cold hand sign" [73-75].

Tison and colleagues [76] reported that about 30\% of patients with MSA-C experience pain. The most common form is musculoskeletal pain, followed by sensory and dystonic pain.

Almost all patients with MSA develop REM sleep behavior disorder (RBD), a condition that is characterized by violent movements and nightmares during REM sleep [77]. In a small series of 13 MSA-C patients, RBD was found to precede waking motor symptoms in 3 patients and was present at diagnosis in about $50 \%$ of cases [78]. Curiously, RBDs commonly improve along with disease progression [75]. Excessive daytime sleepiness has been reported in about $25 \%$ of MSA-C patients, and might stem from low quality of sleep and/or dysfunction in neuronal pathways of arousal $[79,80]$.

Many authors described cognitive impairment, involving executive functions and verbal learning in MSA-C [81-86]. These deficits are probably due to frontal atrophy $[82,84]$ and white matter networks disruption $[81,87]$.

Finally, psychiatric syndromes such as depression [86], anxiety [85] and pathological laughing and crying [88], affect MSA-C patients more frequently than the general population.

\section{Diagnosis}

According to current consensus diagnostic criteria [27], three different categories of increasing diagnostic certainty were defined. A definite diagnosis of MSA requires post-mortem examination. Probable MSA-C is defined by the presence of cerebellar ataxia and either limb ataxia, cerebellar dysarthria or cerebellar oculomotor dysfunction, together with autonomic dysfunction in the form of urinary incontinence and erectile dysfunction or severe orthostatic hypotension defined as a drop in systolic or diastolic blood pressure of $30 \mathrm{mmHg}$ and $15 \mathrm{mmHg}$ within 3 minutes after standing, respectively.

If only a mild autonomic dysfunction is found, possible MSA-C can be diagnosed taking into account pyramidal signs, parkinsonism, and imaging findings. T2-weighted MRI can reveal the so called "hot cross bun sign", a cruciform hyperintensity in the ventral part of pons. This is one of the most distinctive although not pathognomonic imaging findings in MSA-C and has been reported in up to $81.4 \%$ of patients [64]. It is due to demyelation and fibrosis of transverse fibers in pons and it can be assessed also in other pathologies involving the pons, such as different types of SCAs, particularly SCA 2 [89]. Middle cerebellar peduncle hypointensity, lateral putaminal rim hyperintensity and putaminal hypointensity, are also considered in the diagnosis of possible MSA-C.

Diffusion weighted imaging (DWI) and diffusion tensor imaging (DTI) are MRI techniques that are considered still investigational in the latest MSA guidelines [27]. They can detect early alterations in the infratentorial region of MSA patients [90,91] and show a higher sensitivity compared to T2-weighted MRI for the "hot cross bun sign" [92]. Because of its high sensitivity, DTI might be helpful for the differential diagnosis in patients with cerebellar symptoms even in the earlier stages of MSA-C, (see below). DWI and DTI have also been proposed as possible markers for the progression of the disease [93].

Striatal dopaminergic denervation or glucose hypometabolism assessed with SPECT or PET, respectively, in the presence of cerebellar symptoms suggests the diagnosis of MSA-C rather than other forms of late onset ataxia (Table 1).

Warning symptoms, also called "red flags", may facilitate the diagnosis of MSA (Table 2) [94]. Disease progression can be quantified using the Unified MSA Rating Scale (UMSARS) [95]. It involves assessment of the activities of daily living (ADL) (UMSARS I), the motor function (UMSARS II), a simple standing test to determine the presence and magnitude of $\mathrm{OH}$ (UMSARS III) and a global disability scale (UMSARS IV).

\section{Differential diagnosis}

MSA-like cerebellar symptoms, are shared by many other primary and secondary cerebellar disorders. Secondary ataxia can be caused by toxins, infections, tumors, vitamin deficiency and several other pathologies. Primary diseases 
Table 1 Diagnosis of MSA-C, modified from Gilman et al., 2008 [27]

\section{Probable MSA-C:}

A sporadic progressive, adult (>30y)- onset disease characterized by:

- Autonomic failure involving urinary incontinence (inability to control the release of the urine from the bladder, with erectile dysfunction in males) or an orthostatic decrease of blood pressure with 3 min of standing by at least $30 \mathrm{mmHg}$ systolic or $15 \mathrm{mmHg}$ diastolic

- Cerebellar syndrome

\section{Possible MSA-C:}

A sporadic progressive, adult ( $>30 y$ )- onset disease characterized by:

\section{- Cerebellar syndrome}

- At least one feature suggesting autonomic dysfunction (otherwise unexplained urinary urgency, frequency, incomplete bladder emptying, erectile dysfunction, in males, or significant orthostatic blood pressure decline that does not meet the level required in probable MSA-C)

- At least one of the following feature:

o Babinski sing with hyperreflexia

o Stridor

- Parkinsonism (bradykinesia and rigidity)

- Atrophy on MRI of putamen, middle cerebellar peduncle, or pons

- Hypomethabolism on FDG-PET in putamen

o Presynaptic nigrostriatal dopaminergic denervation on PET or SPECT

can be caused by mutations (spinocerebellar ataxias (SCAs) and Fragile-X related tremor and ataxia syndrome (FXTAS)), or remain idiopathic.

Alcohol is a common cause of ataxia, with the percentage of alcoholics developing ataxia ranging from $11 \%$ to $27 \%$
$[96,97]$. The possible relation between alcohol intake and cerebellar symptoms should be carefully assessed for a correct diagnosis. An improvement of symptoms after alcohol withdrawal is strongly indicative for alcoholic ataxia $[98,99]$.

Table 2 Red flags for MSA, reproduced with the courtesy of Wiley and Sons [85]

\begin{tabular}{|c|c|}
\hline Red flag & Definition \\
\hline Early instability with recurrent falls & within 3 years of disease onset \\
\hline Rapid progression & "wheelchair sign": dependent < 10 years from disease onset \\
\hline Orofacial dystonia & based on clinical judgment \\
\hline Camptocormia & prolonged episodes of forward trunk flexion \\
\hline Pisa syndrome & prolonged episodes of lateral trunk flexion \\
\hline Disproportionate antecollis & severe neck flexion, minor flexion elsewhere \\
\hline Contractures of hands or feet & excluding Dupuytren's or contracture due to other known cause \\
\hline Jerky tremor & $\begin{array}{l}\text { irregular postural or action tremor of the hands and/or fingers } \\
\text { with definite myoclonus }\end{array}$ \\
\hline Diurnal inspiratory stridor & based on clinical judgment \\
\hline Nocturnal inspiratory stridor & based on clinical judgment \\
\hline Inspiratory sighs & involuntary deep inspiratory sighs/gasps \\
\hline Severe dysphonia & based on clinical judgment \\
\hline Severe dysarthria & based on clinical judgment \\
\hline Severe dysphagia & based on clinical judgment \\
\hline REM sleep behavior disorder & $\begin{array}{l}\text { intermittent loss of muscle atonia and appearance of elaborate } \\
\text { motor activity (striking out with arms in sleep often with } \\
\text { talking/shouting) associated with dream mentation }\end{array}$ \\
\hline Sleep apnoea & prolonged arrests of breathing \\
\hline Excessive snoring & increase from premorbid level, or newly arising \\
\hline Cold hands/feet & $\begin{array}{l}\text { new development of coldness and color change - purple/blue - of } \\
\text { extremities, with blanching on pressure and poor circulatory return }\end{array}$ \\
\hline Raynaud's phenomenon & new emergence of painful "white fingers" \\
\hline Emotional incontinence - crying & Inappropriate crying without sadness \\
\hline Emotional incontinence - laughing & Inappropriate laughing without mirth \\
\hline Past history of documented hypertension & based on clinical judgment \\
\hline
\end{tabular}


Several drugs can cause cerebellar damage [98,100-103]. It is, therefore, important to evaluate all medications taken by the patients, keeping in mind their possible adverse effects.

An important cause of late onset ataxia is a paraneoplastic syndrome. Small cell lung cancer, ovarian cancer, breast cancer, and Hodgkin's lymphoma are most usually associated with cerebellar injury [98]. This damage is commonly related with the production of circulating antineural antibodies directed against antigens expressed by neoplastic cells [104,105]. Peripheral blood testing, combined with the assessment of rapid progressive ataxia and systemic symptoms such as fever, malaise and anorexia in the absence of cerebellar abnormalities at MRI at the onset of motor symptoms, usually leads to the diagnosis of paraneoplastic cerebellar ataxia within 6 months [104]. Vitamin deficiency, superficial siderosis and infections can also cause ataxia (reviewed by Klockgether, 2010) [98].

Finally, ataxia can also be associated with autoimmune disorders. Anti-glutamate decarboxylase (GAD) antibodies positive ataxia is more frequent in diabetic patients [106] and in patients with polyglandular autoimmune disorder [107]. Gluten ataxia is a sporadic form of ataxia developing after chronic ingestion of gluten, with or without association with coeliac disease. Gluten ataxia is diagnosed if antigliadin antibodies are found in ataxic patients in the absence of other potential causes $[108,109]$. Anti-transglutamminase (TG) autoantibodies can also be found in patients with gluten ataxia. In particular, antibodies directed against TG 6, the most abundant TG isoform in the CNS, are specifically associated with gluten ataxia [110].

The collection of an accurate family history is important, but not always sufficient, to rule out genetic forms of ataxia. Late onset autosomal dominant SCAs, such as SCA6 [111,112], may be difficult to diagnose if the affected relatives died before developing the illness. In a study, genetic analysis was performed in patients with negative family history who developed ataxia when they were at least 25 years old. SCA6 was the predominant genetic form, but also mutations associated with SCA2 and SCA3 were found in few patients [113]. It is worth noting that in Asiatics and Africans SCA2 and SCA3 mutations cause L-DOPA-responsive parkinsonism [114,115].

A premutation of the FMR1 gene causes a late onset form of ataxia called FXTAS. This disease is characterized by cerebellar ataxia, postural and intentional tremor, dementia, neuropathy, and several psychiatric manifestations [116]. A large investigation by Kamm and coworkers (2005) [117] showed that FMR1 premutation-associated ataxia is distinct from MSA-C. Nevertheless, the possible diagnosis of FXTAS has to be considered especially in the presence of slow disease progression, neuropathy and dementia. These clinical features are common among patients with FXTAS, and their assessment may help to differentiate the two disorders.

Most of the above conditions can be diagnosed with an accurate history. It is more difficult to differentiate MSA-C with sporadic adult onset ataxia (SAOA). SAOA, also known as idiopathic late onset cerebellar ataxia (ILOCA), is a rare form of ataxia, with a prevalence of about 8.4 per 100000 [118]. The age at onset for both MSA-C and SAOA is around 50 years [118]. However, the mean survival time is much longer in SAOA than in MSA-C. SAOA is not only associated with a better prognosis but also with a delayed deterioration in ADL. Patients with MSA require a wheelchair within 5 years of onset [64]; in contrast, about half of patients with SAOA can still walk unaided after 12 years [113,119].

A reliable differential diagnosis between SAOA and MSA-C can usually be performed years after the onset. Within 5 years from the diagnosis, about $1 / 4$ of patients with idiopathic late onset cerebellar ataxia are diagnosed as affected by MSA-C $[113,120,121]$. This can be easily explained considering that the presence of autonomic and motor signs is mandatory for the diagnosis of MSA-C [27] and that autonomic dysfunction becomes manifest only 2-2.5 years after the first cerebellar signs $[64,70]$. Initial clinical presentation do not help much in the differential diagnosis. Although nystagmus, gaze paralysis, decreased or absent ankle reflex are more common in SOAO [121,122], many motor and non-motor symptoms [123], RBD [75,122] and erectile dysfunction $[68,122]$, are shared by MSA-C and SAOA.

The differential diagnosis between SAOA and MSA-C has been the subject of several studies. However, the large majority of these studies compared fully developed MSA and SAOA, whereas the differential diagnosis is particularly difficult in the early phase of the disease. T2-weighted MRI is used for the diagnosis of MSA [27] and has good specificity in differentiating fully developed MSA-C from SAOA [124]. Other MRI based techniques were used for the differential diagnosis between MSA-C and other ataxias, with interesting results. Proton MR spectroscopy imaging distinguished MSA-C from SCA2 on the basis of different levels of lactate in cerebellum [125]. DTI yielded a different fractional anisotropy in MSA-C and many other types of ataxia, but not SAOA [126]. A more valuable diagnostic tool is the measurement of cerebral blood flow in the pons by Fine-STR, which is lower in MSA-C than in SAOA [127].

In MSA-C there is loss of motor units innervating the external anal and urethral sphincter muscles reflecting degeneration of Onuf's nucleus. These changes together with detrusor hyperreflexia account for early neurogenic bladder incontinence in MSA-C and they may help differentiate MSA-C from other sporadic late onset cerebellar 
ataxias in the first 5 years after the onset of the disease [128]. Sphincter denervation can be evaluated by means of anal sphincter electromyography (EMG) and urethral sphincter EMG [128-132]. The former is better tolerated by patients [129]. However, anal sphincter EMG is not highly sensitive in the early course of the disease, and it was positive only in $52 \%$ of patients with disease duration shorter than 1 year [130].

Measurements of proteins and monoamine metabolites in the cerebrospinal fluid (CSF) are particularly valuable in the diagnosis of chronic neurodegenerative disorders. Putative CSF biomarkers include neurofilament light chain (NFL), phosphorylated neurofilament heavy chain, $\alpha$-synuclein, $\beta$-amyloid, tau, the noradrenaline metabolite, 3-methoxy-4-hydroxyphenylethylenglycol (MHPG), and the dopamine metabolites, dihydroxyphenylacetic and homovanillic acids [58,133-136]. Abdo et al. (2006) [137] have found that a combined measurement of NFL, MHPG and tau has $100 \%$ specificity in differentiating between MSA and SAOA. Interestingly, the CSF obtained from MSA patients promotes aggregation of $\alpha$-synuclein to a greater extent than the CSF obtained from SCAs patients [138].

For the diagnosis of MSA-C, EMG and CSF analysis are generally not recommended [27], because they are not helpful in full blown cases and have not been jet validated in early cases.

\section{Treatment}

Currently, the only treatments available for MSA-C are symptomatic. There are no approved drugs that can influence the disease course. The management of all possible manifestations of MSA is described in detail elsewhere [139-141]. Here, we will offer a brief description of the main therapeutic options that are currently available and will focus on new drugs under development.

\section{Symptomatic treatment}

Parkinsonism associated with MSA-C is treated with L-DOPA. Only half of patients with MSA-C respond to L-DOPA and dyskinesias, usually facial, are a common side effect [65]. When starting L-DOPA, a responsiveness test should be made with escalating doses in the first 3 months (up to a daily dose of $1000 \mathrm{mg}$ if needed and tolerated) [142].

Currently, there is no treatment for cerebellar ataxia. The hypothesis of a possible effect of anticholinergic drugs is supported by the evidence that nicotine, which stimulates nicotinic cholinergic receptors in the CNS, can cause a reversible worsening of ataxic symptoms $[10,143]$.

Urinary problems could be managed with drugs, at least at the beginning of the disease. The antimuscarinic drug, oxybutinine, reduces detrusor hyperreflexia and sphincter-detrusor dyssynergia, with positive effects on urgency and frequency $[128,144]$. Urinary retention is treated with $\alpha 1$-adrenergic antagonists, such as prazosin and moxysylate. All these drugs have important adverse effects that could limit their use. If postvoid residual volume exceeds $150 \mathrm{ml}$, although potentially difficult for ataxic patients, clean intermittent self-catheterization is indicated [144]. Many patients will eventually require a suprapubic catheter.

Orthostatic hypotension can be managed with nonpharmacological strategies. Adequate hydration of the patient has to be guaranteed [145]. Moreover, the patients should avoid large meals and increase sodium intake. Sitting or lying if feeling dizzy is recommended; if this is not possible, crossing legs, contracting thighs, and bending over can be helpful [146]. Abdominal and leg elastic garments are also effective in reducing orthostatic hypotension. Head-up tilt while sleeping reduces cerebral hypertension and increases circulatory volume within 1 week [140].

If these non-pharmacological measures fail, medical treatment is needed. Fludrocortisone is a potent agonist of mineralcorticoid receptors and increases blood pressure by enhancing sodium reuptake in the kidney. Alternatively, patients may be treated with the $\alpha 1$ adrenergic agonist, midodrine, or with the recently FDA approved adrenergic prodrug, droxidopa [147]. Finally, the vasopressin analogue, desmopressin, reduces nocturnal polyuria and morning hypotension [148].

Patients with postprandial hypotension may gain benefit by treatment with somatostatin analogues [141], which likely act by inhibiting the release of vasoactive gastrointestinal peptides [149].

Constipation is managed with high-fiber diet and, if necessary, macrogol-water solution.

Physiotherapy, speech therapy and occupational therapy may help patients coping with their disease [141].

\section{New treatments}

In the last years, many drugs have been tested as potential disease modifiers in MSA in general and MSA-C in particular. A growing body of evidence suggested efficacy in transgenic MSA mouse models [17]. However, growth hormone $(\mathrm{GH})$ [150], the antiglutamatergic drug, riluzole [151], minocycline [152], rifampicin [153], and lithium [154] all failed to slow or halt disease progression in humans. A common feature of clinical trials with all these drugs, was to include patients in advanced stages, with fewer chances of gaining benefit by putative neuroprotective agents.

A Korean publication [155] reported beneficial effects of autologous bone marrow derived mesenchymal stem cells (MSC) in MSA patients, however these results have not been replicated so far and therefore remain experimentally until further confirmation studies are completed. 
Finally, some interesting results were obtained by intravenous infusion of immunoglobulins, which are known to exert anti-inflammatory activity [156]. Seven MSA patients have been treated for 6 months and showed an improvement in UMSARS I and UMSARS II subscales, whereas UMSARS III and UMSARS IV remained unchanged [157]. This study was carried out on a small number of patients, without a control group. However, bearing in mind that a large deterioration in UMSARS is usually seen in one year [158], results are promising. In addition, $\alpha$-synuclein lowering strategies have shown efficacy in preclinical synucleinopathy models, thus raising the possibility that these strategies may ultimately arrest disease progression in MSA [159].

\section{Conclusions}

Further advances in the diagnosis and treatment of MSA will go hand in hand. Novel neuroprotective strategies will be tested with the aid of novel diagnostic tools that allows an earlier start of the treatment.

Many ancillary exams with possible diagnostic value, such as MRI, anal sphincter EMG, CSF analysis and GH testing have been evaluated in MSA compared to other diseases. In our opinion, it becomes necessary to apply these diagnostic tools in patients with idiopathic cerebellar ataxia $[113,120,121]$. Hopefully, this new techniques will facilitate a differential diagnosis between MSA-C and SAOA at earlier time points. Clearly much is changed and many steps forward have been taken since Quinn portrayed MSA as a beast, in 1989 [160].

\begin{abstract}
Abbreviations
ADL: Activities of daily living; CSF: Cerebrospinal fluid; DARPP-32: Dopamine and C-AMP-regulated phosphoprotein-32; DWI: Diffusion weighted imaging; DTI: Diffusion tensor imaging; EMG: Electromyography; FMR1: Fragile-X mental retardation 1; FXTAS: Fragile $\mathrm{X}$ related tremor and ataxia syndrome; GCls: Glial cytoplasmic inclusions; GH: Growth hormone; ILOCA: Idiopathic late onset cerebellar ataxia; L-DOPA: Levodopa; MHPG: 3-methoxy-4hydroxyphenylethylenglycol; MSA: Multiple system atrophy; MSA-C: Cerebellar type MSA; MSA-P: Parkinsonian type MSA; MSC: Mesenchymal stem cells; NCls: Neuronal cytoplasmic inclusions; NFL: Neurofilament light chain; NNIs: Neuronal nuclear inclusions; OPCA: Olivopontocerebellar atrophy; RBD: REM sleep behavior disorder; SAOA: Sporadic adult onset ataxia; SCAs: Spinocerebellar ataxias; SND: Striatonigral degeneration; SNPs: Single nucleotide polymorphisms; TG: Transglutaminase; TLRs: Toll-like receptors; UMSARS: Unified MSA Rating Scale.
\end{abstract}

\section{Competing interest}

We have no competing interests.

\section{Authors' contributions}

LC defined the search criteria, undertook the literature search, and the analysis and screening of papers, and wrote the paper. FK made critical revisions. FN helped writing the manuscript. GKW defined the search criteria, and made the final revisions. All authors have seen and approved the final version.

\section{Acknowledgement}

This review was supported by funds of the Austrian Science Fund (FWF, SBF F044040-B19)

\section{Author details}

'Sapienza University, Via di Grottarossa, 1035-00189 Rome, Italy. ${ }^{2}$ Department of Neurology, Innsbruck Medical University, Anichstrasse 35, A-6020 Innsbruck, Austria. ${ }^{3}$ RCSS NEUROMED, Pozzilli, Isernia, Italy. ${ }^{4}$ Department of Physiology and Pharmacology "Vittorio Erspamer", Sapienza University, School of Medicine and Psychology, Rome, Italy.

Received: 26 June 2014 Accepted: 24 July 2014

Published online: 10 October 2014

\section{References}

1. Schrag A, Ben-Shlomo Y, Quinn NP: Prevalence of progressive supranuclear palsy and multiple system atrophy: a cross-sectional study. Lancet 1999, 354:1771-5.

2. Wenning GK, Colosimo C, Geser F, Poewe W: Multiple system atrophy. Lancet Neurol 2004, 3:93-103.

3. Bower JH, Maraganore DM, Mcdonnell SK, Rocca WA: Incidence of progressive supranuclear palsy and multiple system atrophy in Olmsted County, Minnesota, 1976 to 1990. Neurology 1997, 49:1284-8.

4. Geser F, Seppi K, Stampfer-Kountchev M, Köllensperger M, Diem A, Ndayisaba JP, Ostergaard K, Dupont E, Cardozo A, Tolosa E, Abele M, Dodel R, Klockgether T, Ghorayeb I, Yekhlef F, Tison F, Daniels C, Kopper F, Deuschl G, Coelho M, Ferreira J, Rosa MM, Sampaio C, Bozi M, Schrag A, Hooker J, Kim H, Scaravilli T, Mathias CJ, Fowler C, et al: The European Multiple System Atrophy-Study Group (EMSA-SG). J Neural Transm 2005, 112:1677-86.

5. Köllensperger M, Geser F, Ndayisaba JP, Boesch S, Seppi K, Ostergaard K, Dupont E, Cardozo A, Tolosa E, Abele M, Klockgether T, Yekhlef F, Tison F, Daniels C, Deuschl G, Coelho M, Sampaio C, Bozi M, Quinn N, Schrag A, Mathias CJ, Fowler C, Nilsson CF, Widner H, Schimke N, Oertel W, Del Sorbo F, Albanese A, Pellecchia MT, Barone P, et al: Presentation, diagnosis, and management of multiple system atrophy in Europe: final analysis of the European multiple system atrophy registry. Mov Disord 2010, 25:2604-12.

6. Wenning GK, Geser F, Krismer F, Seppi K, Duerr S, Boesch S, Köllensperger M, Goebel G, Pfeiffer KP, Barone P, Pellecchia MT, Quinn NP, Koukouni V, Fowler CJ, Schrag A, Mathias CJ, Giladi N, Gurevich T, Dupont E, Ostergaard K, Nilsson CF, Widner H, Oertel W, Eggert KM, Albanese A, del Sorbo F, Tolosa E, Cardozo A, Deuschl G, Hellriegel H, et al: The natural history of multiple system atrophy: a prospective European cohort study. Lancet Neurol 2013, 12:264-74.

7. Yabe I, Soma H, Takei A, Fujiki N, Yanagihara T, Sasaki H: MSA-C is the predominant clinical phenotype of MSA in Japan: analysis of 142 patients with probable MSA. J Neurol Sci 2006, 249:115-21.

8. Ben-Shlomo Y, Wenning GK, Tison F, Quinn NP: Survival of patients with pathologically proven multiple system atrophy: a meta-analysis. Neurology 1997, 48:384-93.

9. Schrag A, Wenning GK, Quinn N, Ben-Shlomo Y: Survival in multiple system atrophy. Mov Disord 2008, 23:294-6.

10. Papp MI, Kahn JE, Lantos PL: Glial cytoplasmic inclusions in the CNS of patients with multiple system atrophy (striatonigral degeneration, olivopontocerebellar atrophy and Shy-Drager syndrome). J Neurol Sci 1989, 94:79-100.

11. Graham JG, Oppenheimer DR: Orthostatic hypotension and nicotine sensitivity in a case of multiple system atrophy. I Neurol Neurosurg Psychiatr 1969, 32:28-34.

12. Wenning GK, Tison F, Elliott L, Quinn NP, Daniel SE: Olivopontocerebellar pathology in multiple system atrophy. Mov Disord 1996, 11:157-62.

13. Ozawa T, Paviour D, Quinn NP, Josephs KA, Sangha H, Kilford L, Healy DG, Wood NW, Lees AJ, Holton JL, Revesz T: The spectrum of pathological involvement of the striatonigral and olivopontocerebellar systems in multiple system atrophy: clinicopathological correlations. Brain 2004, 127:2657-71.

14. Jellinger KA, Seppi K, Wenning GK: Grading of neuropathology in multiple system atrophy: proposal for a novel scale. Mov Disord 2005, 12:529-36.

15. Jecmenica-Lukic M, Poewe W, Tolosa E, Wenning GK: Premotor signs and symptoms of multiple system atrophy. Lancet Neurol 2012, 11:361-8.

16. Cersosimo MG, Benarroch EE: Central control of autonomic function and involvement in neurodegenerative disorders. Handb Clin Neurol 2013, 117:45-57.

17. Kuzdas-Wood D, Stefanova N, Jellinger KA, Seppi K, Schlossmacher MG, Poewe W, Wenning GK: Towards translational therapies for multiple system atrophy. Prog Neurobiol 2014, 118C:19-35. 
18. Orimo S, Kanazawa T, Nakamura A, Uchihara T, Mori F, Kakita A, Wakabayashi K, Takahashi H: Degeneration of cardiac sympathetic nerve can occur in multiple system atrophy. Acta Neuropathol 2007, 113:81-6.

19. Sakakibara R, Hattori T, Uchiyama T, Yamanishi T: Videourodynamic and sphincter motor unit potential analyses in Parkinson's disease and multiple system atrophy. J Neurol Neurosurg Psychiatr 2001, 71:600-6.

20. Sone M, Yoshida M, Hashizume Y, Hishikawa N, Sobue G: alpha-Synucleinimmunoreactive structure formation is enhanced in sympathetic ganglia of patients with multiple system atrophy. Acta Neuropathol 2005, 110:19-26.

21. Provitera V, Nolano M, Caporaso G, Stancanelli A, Manganelli F, lodice R, Selim MM, De Rosa A, Lanzillo B, Pellecchia MT, De Michele G, Santoro L: Postganglionic sudomotor denervation in patients with multiple system atrophy. Neurology 2014, 82:2223-9.

22. Arima K, Uéda K, Sunohara N, Arakawa K, Hirai S, Nakamura M, Tonozuka-Uehara H, Kawai M: NACP/alpha-synuclein immunoreactivity in fibrillary components of neuronal and oligodendroglial cytoplasmic inclusions in the pontine nuclei in multiple system atrophy. Acta Neuropathol 1998, 96:439-44.

23. Spillantini MG, Crowther RA, Jakes R, Cairns NJ, Lantos PL, Goedert M: Filamentous alpha-synuclein inclusions link multiple system atrophy with Parkinson's disease and dementia with Lewy bodies. Neurosci Lett 1998, 251:205-8.

24. Tu PH, Galvin JE, Baba M, Giasson B, Tomita T, Leight S, Nakajo S, Iwatsubo T, Trojanowski JQ, Lee VM: Glial cytoplasmic inclusions in white matter oligodendrocytes of multiple system atrophy brains contain insoluble alpha-synuclein. Ann Neurol 1998, 44:415-22.

25. Wakabayashi K, Yoshimoto M, Tsuji S, Takahashi H: Alpha-synuclein immunoreactivity in glial cytoplasmic inclusions in multiple system atrophy. Neurosci Lett 1998, 249:180-2.

26. Trojanowski JQ, Revesz T: Proposed neuropathological criteria for the post mortem diagnosis of multiple system atrophy. Neuropathol App/ Neurobiol 2007, 33:615-20.

27. Gilman S, Wenning GK, Low PA, Brooks DJ, Mathias CJ, Trojanowski JQ, Wood NW, Colosimo C, Dürr A, Fowler CJ, Kaufmann H, Klockgether T, Lees A, Poewe W, Quinn N, Revesz T, Robertson D, Sandroni P, Seppi K, Vidailhet $\mathrm{M}$ : Second consensus statement on the diagnosis of multiple system atrophy. Neurology 2008, 71:670-6.

28. Papp MI, Lantos PL: The distribution of oligodendroglial inclusions in multiple system atrophy and its relevance to clinical symptomatology. Brain 1994, 117:235-43.

29. Song YJ, Lundvig DM, Huang Y, Gai WP, Blumbergs PC, Højrup P, Otzen D, Halliday GM, Jensen PH: p25alpha relocalizes in oligodendroglia from myelin to cytoplasmic inclusions in multiple system atrophy. Am J Pathol 2007, 171:1291-303

30. Lindersson E, Lundvig D, Petersen C, Madsen P, Nyengaard JR, Højrup P, Moos T, Otzen D, Gai WP, Blumbergs PC, Jensen PH: p25alpha Stimulates alpha-synuclein aggregation and is co-localized with aggregated alpha-synuclein in alpha-synucleinopathies. $J$ Biol Chem 2005, 280:5703-15.

31. Braak H, Rüb U, Del Tredici K: Involvement of precerebellar nuclei in multiple system atrophy. Neuropathol Appl Neurobiol 2003, 29:60-76.

32. Nishie M, Mori F, Yoshimoto M, Takahashi H, Wakabayashi K: A quantitative investigation of neuronal cytoplasmic and intranuclear inclusions in the pontine and inferior olivary nuclei in multiple system atrophy. Neuropathol Appl Neurobiol 2004, 30:546-54.

33. Stefanova N, Bücke P, Duerr S, Wenning GK: Multiple system atrophy: an update. Lancet Neurol 2009, 8:1172-8.

34. Wenning GK, Quinn N, Magalhăes M, Mathias C, Daniel SE: "Minimal change" multiple system atrophy. Mov Disord 1994, 9:161-6.

35. Ishizawa K, Komori T, Arai N, Mizutani T, Hirose T: Glial cytoplasmic inclusions and tissue injury in multiple system atrophy: A quantitative study in white matter (olivopontocerebellar system) and gray matter (nigrostriatal system). Neuropathology 2008, 28:249-57.

36. Yazawa I, Giasson BI, Sasaki R, Zhang B, Joyce S, Uryu K, Trojanowski JQ, Lee VM: Mouse model of multiple system atrophy alpha-synuclein expression in oligodendrocytes causes glial and neuronal degeneration. Neuron 2005, 45:847-59.

37. Ubhi K, Rockenstein E, Mante M, Inglis C, Adame A, Patrick C, Whitney K, Masliah E: Neurodegeneration in a transgenic mouse model of multiple system atrophy is associated with altered expression of oligodendroglial-derived neurotrophic factors. J Neurosci 2010, 30:6236-46.
38. The Multiple-System Atrophy Research Collaboration: Mutations in COQ2 in familial and sporadic multiple-system atrophy. N Engl J Med 2013, 369:233-44

39. Blin O, Desnuelle C, Rascol O, Borg M, Peyro Saint Paul H, Azulay JP, Billé F, Figarella D, Coulom F, Pellissier JF, et al: Mitochondrial respiratory failure in skeletal muscle from patients with Parkinson's disease and multiple system atrophy [abstract]. J Neurol Sci 1994, 125:95-101.

40. Yamashita T, Ando Y, Obayashi K, Terazaki H, Sakashita N, Uchida K, Ohama E, Ando M, Uchino M: Oxidative injury is present in Purkinje cells in patients with olivopontocerebellar atrophy. J Neuro/ Sci 2000, 175:107-10.

41. Riedel M, Goldbaum O, Richter-Landsberg C: alpha-Synuclein promotes the recruitment of tau to protein inclusions in oligodendroglial cells: effects of oxidative and proteolytic stress. J Mol Neurosci 2009, 39:226-34.

42. Stefanova N, Reindl M, Neumann M, Haass C, Poewe W, Kahle PJ, Wenning GK: Oxidative stress in transgenic mice with oligodendroglial alpha-synuclein overexpression replicates the characteristic neuropathology of multiple system atrophy. Am J Pathol 2005, 166:869-76.

43. Koutsilieri E, Scheller C, Tribl F, Riederer P: Degeneration of neuronal cells due to oxidative stress-microglial contribution. Parkinsonism Relat Disord 2002, 8:401-6.

44. Vilhardt F: Microglia: phagocyte and glia cell. Int J Biochem Cell Biol 2005, 37:17-21.

45. Stefanova N, Reindl M, Neumann M, Kahle PJ, Poewe W, Wenning GK: Microglial activation mediates neurodegeneration related to oligodendroglial alpha-synucleinopathy: implications for multiple system atrophy. Mov Disord 2007, 22:2196-203.

46. Brudek T, Winge K, Agander TK, Pakkenberg B: Screening of Toll-like receptors expression in multiple system atrophy brains. Neurochem Res 2013, 38:1252-9.

47. Amor S, Puentes F, Baker D, Van der Valk P: Inflammation in neurodegenerative diseases. Immunology 2010, 129:154-69.

48. Stefanova N, Fellner L, Reindl M, Masliah E, Poewe W, Wenning GK: Toll-like receptor 4 promotes a-synuclein clearance and survival of nigral dopaminergic neurons. Am J Pathol 2011, 179:954-63.

49. Wülner U, Abele M, Schmitz-Huebsch T, Wilhelm K, Benecke R, Deuschl G, Klockgether T: Probable multiple system atrophy in a German family. J Neurol Neurosurg Psychiatr 2004, 75:924-5.

50. Soma H, Yabe I, Takei A, Fujiki N, Yanagihara T, Sasaki H: Heredity in multiple system atrophy. J Neurol Sci 2006, 240:107-10.

51. Hara K, Momose Y, Tokiguchi S, Shimohata M, Terajima K, Onodera O, Kakita A, Yamada M, Takahashi H, Hirasawa M, Mizuno Y, Ogata K, Goto J, Kanazawa I, Nishizawa M, Tsuji S: Multiplex families with multiple system atrophy. Arch Neurol 2007, 64:545-51.

52. Al-Chalabi A, Dürr A, Wood NW, Parkinson MH, Camuzat A, Hulot JS, Morrison KE, Renton A, Sussmuth SD, Landwehrmeyer BG, Ludolph A, Agid Y, Brice A, Leigh PN, Bensimon G, NNIPPS Genetic Study Group: Genetic variants of the alpha-synuclein gene SNCA are associated with multiple system atrophy. PLoS One 2009, 4:e7114.

53. Scholz SW, Houlden H, Schulte C, Sharma M, Li A, Berg D, Melchers A, Paudel R, Gibbs JR, Simon-Sanchez J, Paisan-Ruiz C, Bras J, Ding J, Chen H, Traynor BJ, Arepalli S, Zonozi RR, Revesz T, Holton J, Wood N, Lees A, Oertel W, Wüllner U, Goldwurm S, Pellecchia MT, Illig T, Riess O, Fernandez HH, Rodriguez RL, et al: SNCA variants are associated with increased risk for multiple system atrophy. Ann Neurol 2009, 65:610-4.

54. Kiely AP, Asi YT, Kara E, Limousin P, Ling H, Lewis P, Proukakis C, Quinn N, Lees AJ, Hardy J, Revesz T, Houlden H, Holton JL: a-Synucleinopathy associated with G51D SNCA mutation: a link between Parkinson's disease and multiple system atrophy? Acta Neuropathol 2013, 125:753-69.

55. Shibao C, Garland EM, Gamboa A, Vnencak-Jones CL, Van Woeltz M, Haines JL, Yu C, Biaggioni I: PRNP M129V homozygosity in multiple system atrophy vs. Parkinson's disease. Clin Auton Res 2008, 18:13-9.

56. Miller DW, Johnson JM, Solano SM, Hollingsworth ZR, Standaert DG, Young $A B$ : Absence of alpha-synuclein mRNA expression in normal and multiple system atrophy oligodendroglia. J Neural Transm 2005, 112:1613-24.

57. Asi YT, Simpson JE, Heath PR, Wharton SB, Lees AJ, Revesz T: Houlden H. Holton J: Alpha-synuclein mRNA expression in oligodendrocytes in MSA. Glia; 2014.

58. Mollenhauer B, Locascio JJ, Schulz-Schaeffer W, Sixel-Döring F, Trenkwalder C, Schlossmacher MG: $a-S y n u c l e i n$ and tau concentrations in cerebrospinal fluid of patients presenting with parkinsonism: a cohort study. Lancet Neurol 2011, 10:230-40 
59. Borghi R, Marchese R, Negro A, Marinelli L, Forloni G, Zaccheo D, Abbruzzese G, Tabaton M: Full length alpha-synuclein is present in cerebrospinal fluid from Parkinson's disease and normal subjects. Neurosci Lett 2000, 287:65-7.

60. Wenning GK, Stefanova N, Jellinger KA, Poewe W, Schlossmacher MG: Multiple system atrophy: a primary oligodendrogliopathy. Ann Neurol 2008, 64:239-46.

61. Reyes JF, Rey NL, Bousset L, Melki R, Brundin P, Angot E: Alpha-synuclein transfers from neurons to oligodendrocytes. Glia 2014, 62:387-98.

62. Angot E, Steiner JA, Hansen C, Li JY, Brundin P: Are synucleinopathies prion-like disorders? Lancet Neurol 2010, 9:1128-38.

63. Watts JC, Giles K, Oehler A, Middleton L, Dexter DT, Gentleman SM, DeArmond SJ, Prusiner SB: Transmission of multiple system atrophy prions to transgenic mice. Proc Natl Acad Sci U S A 2013, 110:19555-60.

64. Watanabe H, Saito Y, Terao S, Ando T, Kachi T, Mukai E, Aiba I, Abe Y, Tamakoshi A, Doyu M, Hirayama M, Sobue G: Progression and prognosis in multiple system atrophy: an analysis of 230 Japanese patients. Brain 2002, 125:1070-83.

65. Wüllner U, Schmitz-Hübsch T, Abele M, Antony G, Bauer P, Eggert K: Features of probable multiple system atrophy patients identified among 4770 patients with parkinsonism enrolled in the multicentre registry of the German Competence Network on Parkinson's disease. J Neural Transm 2007, 114:1161-5.

66. Kirchhof K, Apostolidis AN, Mathias CJ, Fowler CJ: Erectile and urinary dysfunction may be the presenting features in patients with multiple system atrophy: a retrospective study. Int J Impot Res 2003, 15:293-8.

67. Ito T, Sakakibara R, Yasuda K, Yamamoto T, Uchiyama T, Liu Z, Yamanishi T, Awa $Y$, Yamamoto $K$, Hattori T: Incomplete emptying and urinary retention in multiple-system atrophy: when does it occur and how do we manage it? Mov Disord 2006, 21:816-23.

68. Wenning GK, Ben-Shlomo Y, Magalhães M, Daniel SE, Quinn NP: Clinical features and natural history of multiple system atrophy. An analysis of 100 cases. Brain 1994, 117:835-45.

69. Iodice V, Lipp A, Ahlskog JE, Sandroni P, Fealey RD, Parisi JE, Matsumoto JY, Benarroch EE, Kimpinski K, Singer W, Gehrking TL, Gehrking JA, Sletten DM, Schmeichel AM, Bower JH, Gilman S, Figueroa J, Low PA: Autopsy confirmed multiple system atrophy cases: Mayo experience and role of autonomic function tests. J Neurol Neurosurg Psychiatr 2012, 83:453-9.

70. Tada M, Onodera O, Tada M, Ozawa T, Piao YS, Kakita A, Takahashi H, Nishizawa M: Early development of autonomic dysfunction may predict poor prognosis in patients with multiple system atrophy. Arch Neurol 2007, 64:256-60

71. Isozaki E, Naito A, Horiguchi S, Kawamura R, Hayashida T, Tanabe H: Early diagnosis and stage classification of vocal cord abductor paralysis in patients with multiple system atrophy. J Neurol Neurosurg Psychiatr 1996, 60:399-402.

72. Müller J, Wenning GK, Jellinger K, Mckee A, Poewe W, Litvan I: Progression of Hoehn and Yahr stages in Parkinsonian disorders: a clinicopathologic study. Neurology 2000, 55:888-91.

73. Asahina M, Low DA, Mathias CJ, Fujinuma Y, Katagiri A, Yamanaka Y, Shimada J, Poudel A, Kuwabara S: Skin temperature of the hand in multiple system atrophy and Parkinson's disease. Parkinsonism Relat Disord 2013, 19:560-2.

74. Klein C, Brown R, Wenning G, Quinn N: The "cold hands sign" in multiple system atrophy. Mov Disord 1997, 12:514-8

75. Quinn NP: How to diagnose multiple system atrophy. Mov Disord 2005, 20(Suppl 12):S5-S10.

76. Tison F, Wenning GK, Volonte MA, Poewe WR, Henry P, Quinn NP: Pain in multiple system atrophy. J Neurol 1996, 243:153-6.

77. Iranzo A, Santamaría J, Rye DB, Valldeoriola F, Martí MJ, Muñoz E, Vilaseca I, Tolosa E: Characteristics of idiopathic REM sleep behavior disorder and that associated with MSA and PD. Neurology 2005, 65:247-52.

78. Vetrugno R, Provini F, Cortelli P, Plazzi G, Lotti EM, Pierangeli G, Canali C, Montagna P: Sleep disorders in multiple system atrophy: a correlative video-polysomnographic study. Sleep Med 2004, 5:21-30.

79. Moreno-López C, Santamaría J, Salamero M, Del Sorbo F, Albanese A, Pellecchia MT, Barone P, Overeem S, Bloem B, Aarden W, Canesi M, Antonini A, Duerr S, Wenning GK, Poewe W, Rubino A, Meco G, Schneider SA, Bhatia KP, Djaldetti R, Coelho M, Sampaio C, Cochen V, Hellriegel H, Deuschl G, Colosimo C, Marsili L, Gasser T, Tolosa E: Excessive daytime sleepiness in multiple system atrophy (SLEEMSA study). Arch Neurol 2011, 68:223-30.
80. Shimohata T, Nakayama H, Tomita M, Ozawa T, Nishizawa M: Daytime sleepiness in Japanese patients with multiple system atrophy: prevalence and determinants. BMC Neurol 2012, 12:130.

81. Bürk K, Daum I, Rüb U: Cognitive function in multiple system atrophy of the cerebellar type. Mov Disord 2006, 21:772-6.

82. Kawai Y, Suenaga M, Takeda A, Ito M, Watanabe H, Tanaka F, Kato K Fukatsu H, Naganawa S, Kato T, Ito K, Sobue G: Cognitive impairments in multiple system atrophy: MSA-C vs MSA-P. Neurology 2008, 70:1390-6.

83. Kitayama M, Wada-Isoe K, Irizawa Y, Nakashima K: Assessment of dementia in patients with multiple system atrophy. Eur J Neurol 2009, 16:589-94.

84. Chang CC, Chang YY, Chang WN, Lee YC, Wang YL, Lui CC, Huang CW, Liu WL: Cognitive deficits in multiple system atrophy correlate with frontal atrophy and disease duration. Eur J Neurol 2009, 16:1144-50.

85. Balas M, Balash Y, Giladi N, Gurevich T: Cognition in multiple system atrophy: neuropsychological profile and interaction with mood. J Neural Transm 2010, 117:369-75.

86. Siri C, Duerr S, Canesi M, Delazer M, Esselink R, Bloem BR, Gurevich T, Balas M, Giladi N, Santacruz P, Marti F, Tolosa E, Rubino A, Meco G, Poewe W, Pezzoli G, Wenning G, Antonini A: A cross-sectional multicenter study of cognitive and behavioural features in multiple system atrophy patients of the parkinsonian and cerebellar type. J Neural Transm 2013, 120:613-8.

87. Lu CF, Soong BW, Wu HM, Teng S, Wang PS, Wu YT: Disrupted cerebellar connectivity reduces whole-brain network efficiency in multiple system atrophy. Mov Disord 2013, 28:362-9.

88. Parvizi J, Joseph J, Press DZ, Schmahmann JD: Pathological laughter and crying in patients with multiple system atrophy-cerebellar type. Mov Disord 2007, 22:798-803.

89. Lee YC, Liu CS, Wu HM, Wang PS, Chang MH, Soong BW: The 'hot cross bun' sign in the patients with spinocerebellar ataxia. Eur J Neurol 2009, 16:513-6.

90. Kanazawa M, Shimohata T, Terajima K, Onodera O, Tanaka K, Tsuji S, Okamoto K, Nishizawa M: Quantitative evaluation of brainstem involvement in multiple system atrophy by diffusion-weighted MR imaging. J Neurol 2004, 251:1121-4.

91. Oishi K, Konishi J, Mori S, Ishihara H, Kawamitsu H, Fujii M, Kanda F: Reduced fractional anisotropy in early-stage cerebellar variant of multiple system atrophy. J Neuroimaging 2009, 19:127-31.

92. Kasahara S, Miki Y, Kanagaki M, Kondo T, Yamamoto A, Morimoto E, Okada T, Ito H, Takahashi R, Togashi K: "Hot cross bun" sign in multiple system atrophy with predominant cerebellar ataxia: a comparison between proton density-weighted imaging and T2-weighted imaging. Eur J Radiol 2012, 81:2848-52.

93. Pellecchia MT, Barone P, Vicidomini C, Mollica C, Salvatore E, lanniciello M, Liuzzi R, Longo K, Picillo M, De Michele G, Filla A, Brunetti A, Salvatore M, Pappatà S: Progression of striatal and extrastriatal degeneration in multiple system atrophy: a longitudinal diffusion-weighted MR study. Mov Disord 2011, 26:1303-9.

94. Köllensperger M, Geser F, Seppi K, Stampfer-Kountchev M, Sawires M, Scherfler C, Boesch S, Mueller J, Koukouni V, Quinn N, Pellecchia MT, Barone P, Schimke N, Dodel R, Oertel W, Dupont E, Østergaard K, Daniels C, Deuschl G, Gurevich T, Giladi N, Coelho M, Sampaio C, Nilsson C, Widner H, Sorbo FD, Albanese A, Cardozo A, Tolosa E, Abele M: Red flags for multiple system atrophy. Mov Disord 2008, 23:1093-9.

95. Wenning GK, Tison F, Seppi K, Sampaio C, Diem A, Yekhlef F, Ghorayeb I, Ory F, Galitzky M, Scaravilli T, Bozi M, Colosimo C, Gilman S, Shults CW, Quinn NP, Rascol O, Poewe W, Multiple System Atrophy Study Group: Development and validation of the Unified Multiple System Atrophy Rating Scale (UMSARS). Mov Disord 2004, 19:1391-402.

96. Torvik A, Torp S: The prevalence of alcoholic cerebellar atrophy. A morphometric and histological study of an autopsy material. J Neurol Sci 1986, 75:43-51.

97. Yokota O, Tsuchiya K, Terada S, Oshima K, Ishizu H, Matsushita M, Kuroda S, Akiyama $\mathrm{H}$ : Frequency and clinicopathological characteristics of alcoholic cerebellar degeneration in Japan: a cross-sectional study of 1,509 postmortems. Acta Neuropathol 2006, 112:43-51.

98. Klockgether T: Sporadic ataxia with adult onset: classification and diagnostic criteria. Lancet Neurol 2010, 9:94-104.

99. Diener HC, Dichgans J, Bacher M, Guschlbauer B: Improvement of ataxia in alcoholic cerebellar atrophy through alcohol abstinence [abstract]. J Neurol 1984, 231:258-62. 
100. Lazarus HM, Herzig RH, Herzig GP, Phillips GL, Roessmann U, Fishman DJ: Central nervous system toxicity of high-dose systemic cytosine arabinoside. Cancer 1981, 48:2577-82

101. Kores B, Lader MH: Irreversible lithium neurotoxicity: an overview. Clin Neuropharmacol 1997, 20:283-99.

102. Bygrave HA, Geh Jl, Jani Y, Glynne-Jones R: Neurological complications of 5-fluorouracil chemotherapy: case report and review of the literature. Clin Oncol (R Coll Radiol) 1998, 10:334-6.

103. Orr CF, Ahlskog JE: Frequency, characteristics, and risk factors for amiodarone neurotoxicity. Arch Neurol 2009, 66:865-9.

104. Shams'ili S, Grefkens J, De Leeuw B, van den Bent M, Hooijkaas H, van der Holt B, Vecht C, Sillevis Smitt P: Paraneoplastic cerebellar degeneration associated with antineuronal antibodies: analysis of 50 patients. Brain 2003, 126:1409-18

105. Vianello M, Vitaliani R, Pezzani R, Nicolao P, Betterle C, Keir G, Thompson EJ, Tavolato B, Scaravilli F, Giometto B: The spectrum of antineuronal autoantibodies in a series of neurological patients. J Neurol Sci 2004, 220:29-36.

106. Honnorat J, Saiz A, Giometto B, Vincent A, Brieva L, de Andres C, Maestre J, Fabien N, Vighetto A, Casamitjana R, Thivolet C, Tavolato B, Antoine J, Trouillas P, Graus F: Cerebellar ataxia with anti-glutamic acid decarboxylase antibodies: study of 14 patients. Arch Neuro/ 2001, 58:225-30.

107. Vianello M, Tavolato B, Armani M, Giometto B: Cerebellar ataxia associated with anti-glutamic acid decarboxylase autoantibodies. Cerebellum 2003, 2:77-9.

108. Hadjivassiliou M, Grünewald RA, Chattopadhyay AK, Davies-Jones GA, Gibson A, Jarratt JA, Kandler RH, Lobo A, Powell T, Smith CM: Clinical, radiological, neurophysiological, and neuropathological characteristics of gluten ataxia. Lancet 1998, 352:1582-5.

109. Hadjivassiliou M, Grünewald R, Sharrack B, Sanders D, Lobo A, Williamson C, Woodroofe N, Wood N, Davies-Jones A: Gluten ataxia in perspective: epidemiology, genetic susceptibility and clinical characteristics. Brain 2003, 126:685-91.

110. Hadjivassiliou M, Aeschlimann P, Strigun A, Sanders DS, Woodroofe N, Aeschlimann D: Autoantibodies in gluten ataxia recognize a novel neuronal transglutaminase. Ann Neurol 2008, 64:332-43.

111. Ikeuchi T, Takano H, Koide R, Horikawa Y, Honma Y, Onishi Y, Igarashi S, Tanaka H, Nakao N, Sahashi K, Tsukagoshi H, Inoue K, Takahashi H, Tsuji S: Spinocerebellar ataxia type 6: CAG repeat expansion in alpha1A voltage-dependent calcium channel gene and clinical variations in Japanese population. Ann Neurol 1997, 42:879-84.

112. Schöls L, Krüger R, Amoiridis G, Przuntek H, Epplen JT, Riess O: Spinocerebellar ataxia type 6: genotype and phenotype in German kindreds. J Neurol Neurosurg Psychiatr 1998, 64:67-73.

113. Abele M, Bürk K, Schöls L, Schwartz S, Besenthal I, Dichgans J, Zühlke C, Riess $\mathrm{O}$, Klockgether $\mathrm{T}$ : The aetiology of sporadic adult-onset ataxia. Brain 2002, 125:961-8.

114. Subramony SH, Hernandez D, Adam A, Smith-Jefferson S, Hussey J, Gwinn-Hardy K, Lynch T, McDaniel O, Hardy J, Farrer M, Singleton A: Ethnic differences in the expression of neurodegenerative disease: Machado-Joseph disease in Africans and Caucasians. Mov Disord 2002, 17:1068-71.

115. Nirenberg MJ, Libien J, Vonsattel JP, Fahn S: Multiple system atrophy in a patient with the spinocerebellar ataxia 3 gene mutation. Mov Disord 2007, 22:251-4.

116. Berry-Kravis E, Abrams L, Coffey SM, Hall DA, Greco C, Gane LW, Grigsby J, Bourgeois JA, Finucane B, Jacquemont S, Brunberg JA, Zhang L, Lin J, Tassone F, Hagerman PJ, Hagerman RJ, Leehey MA: Fragile X-associated tremor/ataxia syndrome: clinical features, genetics, and testing guidelines. Mov Disord 2007, 22:2018-30.

117. Kamm C, Healy DG, Quinn NP, Wüllner U, Moller JC, Schols L, Geser F, Burk K, Børglum AD, Pellecchia MT, Tolosa E, del Sorbo F, Nilsson C, Bandmann O, Sharma M, Mayer P, Gasteiger M, Haworth A, Ozawa T, Lees AJ, Short J, Giunti P, Holinski-Feder E, Illig T, Wichmann HE, Wenning GK, Wood NW, Gasser T, European Multiple System Atrophy Study Group: The fragile $X$ tremor ataxia syndrome in the differential diagnosis of multiple system atrophy: data from the EMSA Study Group. Brain 2005, 128:1855-60.

118. Muzaimi MB, Thomas J, Palmer-Smith S, Rosser L, Harper PS, Wiles CM, Ravine D, Robertson NP: Population based study of late onset cerebellar ataxia in south east Wales. J Neurol Neurosurg Psychiatr 2004, 75:1129-34.
119. Klockgether T, Schroth G, Diener HC, Dichgans J: Idiopathic cerebellar ataxia of late onset: natural history and MRI morphology. J Neurol Neurosurg Psychiatr 1990, 53:297-305.

120. Gilman S, Little R, Johanns J, Heumann M, Kluin KJ, Junck L, Koeppe RA, $\mathrm{An} \mathrm{H}$ : Evolution of sporadic olivopontocerebellar atrophy into multiple system atrophy. Neurology 2000, 55:527-32

121. Berciano J, Boesch S, Pérez-Ramos JM, Wenning GK: Olivopontocerebellar atrophy: toward a better nosological definition. Mov Disord 2006, 21:1607-13.

122. Abele M, Minnerop M, Urbach $H$, Specht K, Klockgether T: Sporadic adult onset ataxia of unknown etiology : a clinical, electrophysiological and imaging study. J Neurol 2007, 254:1384-9.

123. Abele M, Riet A, Hummel T, Klockgether T, Wüllner U: Olfactory dysfunction in cerebellar ataxia and multiple system atrophy. J Neurol 2003, 250:1453-5.

124. Burk K, Globas C, Wahl T, Bühring U, Dietz K, Zuhlke C, Luft A, Schulz JB, Voigt K, Dichgans J: MRI-based volumetric differentiation of sporadic cerebellar ataxia. Brain 2004, 127:175-81.

125. Boesch SM, Wolf C, Seppi K, Felber S, Wenning GK, Schocke M: Differentiation of SCA2 from MSA-C using proton magnetic resonance spectroscopic imaging. J Magn Reson Imaging 2007, 25:564-9.

126. Prakash N, Hageman N, Hua X, Toga AW, Perlman SL, Salamon N: Patterns of fractional anisotropy changes in white matter of cerebellar peduncles distinguish spinocerebellar ataxia-1 from multiple system atrophy and other ataxia syndromes. Neuroimage 2009, 47(Suppl 2):T72-81.

127. Kimura N, Kumamoto T, Masuda T, Nomura Y, Hanaoka T, Hazama Y, Okazaki T: Evaluation of regional cerebral blood flow in cerebellar variant of multiple system atrophy using FineSRT. Clin Neurol Neurosurg 2009, 111:829-34.

128. Vodusek DB: Sphincter EMG and differential diagnosis of multiple system atrophy [abstract]. Mov Disord 2001, 16:600-7.

129. Beck RO, Betts CD, Fowler CJ: Genitourinary dysfunction in multiple system atrophy: clinical features and treatment in 62 cases. J Urol 1994, 151:1336-41.

130. Yamamoto T, Sakakibara R, Uchiyama T, Liu Z, Ito T, Awa Y, Yamamoto K, Kinou M, Yamanishi T, Hattori T: When is Onuf's nucleus involved in multiple system atrophy? A sphincter electromyography study. J Neurol Neurosurg Psychiatr 2005, 76:1645-8.

131. Pramstaller PP, Wenning GK, Smith SJ, Beck RO, Quinn NP, Fowler CJ: Nerve conduction studies, skeletal muscle EMG, and sphincter EMG in multiple system atrophy. J Neurol Neurosurg Psychiatr 1995, 58:618-21.

132. Wenning GK, Kraft E, Beck R, Fowler CJ, Mathias CJ, Quinn NP, Harding AE: Cerebellar presentation of multiple system atrophy. Mov Disord 1997, 12:115-7.

133. Brettschneider J, Petzold A, Süssmuth SD, Landwehrmeyer GB, Ludolph AC, Kassubek J, Tumani H: Neurofilament heavy-chain NfH(SMI35) in cerebrospinal fluid supports the differential diagnosis of Parkinsonian syndromes. Mov Disord 2006, 21:2224-7.

134. Constantinescu R, Rosengren $L$, Johnels B, Zetterberg $H$, Holmberg B: Consecutive analyses of cerebrospinal fluid axonal and glial markers in Parkinson's disease and atypical Parkinsonian disorders. Parkinsonism Relat Disord 2010, 16:142-5.

135. Bech S, Hjermind LE, Salvesen L, Nielsen JE, Heegaard NH, Jørgensen HL, Rosengren L, Blennow K, Zetterberg H, Winge K: Amyloid-related biomarkers and axonal damage proteins in parkinsonian syndromes. Parkinsonism Relat Disord 2012, 18:69-72.

136. Goldstein DS, Holmes C, Sharabi Y: Cerebrospinal fluid biomarkers of central catecholamine deficiency in Parkinson's disease and other synucleinopathies. Brain 2012, 135:1900-13.

137. Abdo WF, Van de Warrenburg BP, Munneke M, van Geel WJ, Bloem BR Kremer HP, Verbeek MM: CSF analysis differentiates multiple-system atrophy from idiopathic late-onset cerebellar ataxia. Neurology 2006, 67:474-9.

138. Hirohata M, Ono K, Morinaga A, Ikeda T, Yamada M: Cerebrospinal fluid from patients with multiple system atrophy promotes in vitro asynuclein fibril formation. Neurosci Lett 2011, 491:48-5

139. Colosimo C, Tiple D, Wenning GK: Management of multiple system atrophy: state of the art. J Neural Transm 2005, 112:1695-704.

140. Wenning GK, Geser F, Poewe W: Therapeutic strategies in multiple system atrophy. Mov Disord 2005, 20(Suppl 12):S67-76.

141. Wenning GK, Stefanova N: Recent developments in multiple system atrophy. J Neurol 2009, 256:1791-808 
142. Gilman S, Low PA, Quinn N, Albanese A, Ben-Shlomo Y, Fowler CJ, Kaufmann H, Klockgether T, Lang AE, Lantos PL, Litvan I, Mathias CJ, Oliver E, Robertson D, Schatz I, Wenning GK: Consensus statement on the diagnosis of multiple system atrophy. J Neurol Sci 1999, 163:94-8.

143. Colosimo C, Inghilleri M: A further case of nicotine sensitivity in multiple system atrophy. Clin Neuropharmacol 2012, 35:51-2

144. Winge K, Fowler CJ: Bladder dysfunction in Parkinsonism: mechanisms, prevalence, symptoms, and management. Mov Disord 2006, 21:737-45.

145. Shannon JR, Diedrich A, Biaggioni I, Tank J, Robertson RM, Robertson D, Jordan J: Water drinking as a treatment for orthostatic syndromes. Am J Med 2002, 112:355-60.

146. Low PA, Singer W: Management of neurogenic orthostatic hypotension: an update. Lancet Neurol 2008, 7:451-8.

147. Hauser RA, Hewitt LA, Isaacson S: Droxidopa in patients with neurogenic orthostatic hypotension associated with Parkinson's disease (NOH306A). J Parkinsons Dis 2014, 4:57-65.

148. Low PA, Gilden JL, Freeman R, Sheng KN, McElligott MA: Efficacy of midodrine vs placebo in neurogenic orthostatic hypotension. A randomized, double-blind multicenter study. Midodrine Study Group. JAMA 1997, 277:1046-51.

149. Raimbach SJ, Cortelli P, Kooner JS, Bannister R, Bloom SR, Mathias C Prevention of glucose-induced hypotension by the somatostatin analogue octreotide (SMS 201-995) in chronic autonomic failure: haemodynamic and hormonal changes. Clin Sci 1989, 77:623-8.

150. Holmberg B, Johansson JO, Poewe W, Wenning G, Quinn NP, Mathias C, Tolosa E, Cardozo A, Dizdar N, Rascol O, Slaoui T, Growth-Hormone MSA Study Group, European MSA Study Group: Safety and tolerability of growth hormone therapy in multiple system atrophy: a double-blind, placebo-controlled study. Mov Disord 2007, 22:1138-44.

151. Bensimon G, Ludolph A, Agid Y, Vidailhet M, Payan C, Leigh PN, NNIPPS Study Group: Riluzole treatment, survival and diagnostic criteria in Parkinson plus disorders: the NNIPPS study. Brain 2009, 132:156-71

152. Dodel R, Spottke A, Gerhard A, Reuss A, Reinecker S, Schimke N, Trenkwalder C, Sixel-Döring F, Herting B, Kamm C, Gasser T, Sawires M, Geser F, Köllensperger M, Seppi K, Kloss M, Krause M, Daniels C, Deuschl G, Böttger S, Naumann M, Lipp A, Gruber D, Kupsch A, Du Y, Turkheimer F, Brooks DJ, Klockgether T, Poewe W, Wenning G, et al: Minocycline 1-year therapy in multiple-system-atrophy: effect on clinical symptoms and [(11)C] (R)-PK11195 PET (MEMSA-trial). Mov Disord 2010, 25:97-107.

153. Low PA, Robertson D, Gilman S, Kaufmann H, Singer W, Biaggioni I, Freeman R, Perlman S, Hauser RA, Cheshire W, Lessig S, Vernino S, Mandrekar J, Dupont WD, Chelimsky T, Galpern WR: Efficacy and safety of rifampicin for multiple system atrophy: a randomised, double-blind, placebo-controlled trial. Lancet Neurol 2014, 13:268-75.

154. Saccà F, Marsili A, Quarantelli M, Brescia Morra V, Brunetti A, Carbone R, Pane C, Puorro G, Russo CV, Salvatore E, Tucci T, De Michele G, Filla A: A randomized clinical trial of lithium in multiple system atrophy. J Neurol 2013, 260:458-61.

155. Lee $\mathrm{PH}$, Lee JE, Kim HS, Song SK, Lee HS, Nam HS, Cheong JW, Jeong $Y$, Park HJ, Kim DJ, Nam CM, Lee JD, Kim HO, Sohn YH: A randomized trial of mesenchymal stem cells in multiple system atrophy. Ann Neurol 2012, 72:32-40.

156. Aktas O, Zipp F: Regulation of self-reactive $T$ cells by human immunoglobulins-implications for multiple sclerosis therapy. Curr Pharm Des 2003, 9:245-56.

157. Novak P, Williams A, Ravin P, Zurkiya O, Abduljalil A, Novak V: Treatment of multiple system atrophy using intravenous immunoglobulin. BMC Neurol 2012, 12:131.

158. Geser F, Wenning GK, Seppi K, Stampfer-Kountchev M, Scherfler C, Sawires M, Frick C, Ndayisaba JP, Ulmer H, Pellecchia MT, Barone P, Kim HT, Hooker J, Quinn NP, Cardozo A, Tolosa E, Abele M, Klockgether T, Østergaard K, Dupont E, Schimke N, Eggert KM, Oertel W, Djaldetti R, Poewe W, European MSA Study Group: Progression of multiple system atrophy (MSA): a prospective natural history study by the European MSA Study Group (EMSA SG). Mov Disord 2006, 21:179-86.

159. Krismer F, Jellinger KA, Scholz SW, Seppi K, Stefanova N, Antonini A, Poewe W, Wenning GK: Multiple system atrophy as emerging template for accelerated drugs discovery in a-synucleinopathies. Parkinsonism Relat Disord in press.

160. Quinn N: Multiple system atrophy-the nature of the beast. J Neurol Neurosurg Psychiatr 1989, Suppl:78-89.

doi:10.1186/s40673-014-0014-7

Cite this article as: Ciolli et al:: An update on the cerebellar subtype of multiple system atrophy. Cerebellum \& Ataxias 2014 1:14.

\section{Submit your next manuscript to BioMed Central and take full advantage of:}

- Convenient online submission

- Thorough peer review

- No space constraints or color figure charges

- Immediate publication on acceptance

- Inclusion in PubMed, CAS, Scopus and Google Scholar

- Research which is freely available for redistribution

Submit your manuscript at www.biomedcentral.com/submit
C) Biomed Central 